\title{
Effect of lupins and pasture on soil acidification and fertility in Western Australia
}

\author{
S.P.Loss , G. S.P. Ritchie and A.D. Robson
}

Summary. An 'across the fence' comparison of farmer paddocks with nearby virgin bush sites was made at 3 locations, to measure the effects of lupins and subterranean clover based pastures on the chemical properties of the soil.

Estimated rates of acidification in the $0-60 \mathrm{~cm}$ depth

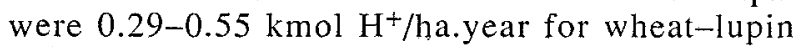
paddocks and $0.16-0.21 \mathrm{kmol} \mathrm{H}^{+} /$ha year for pasture paddocks. A significant proportion of this acidification

occurred below $20 \mathrm{~cm}$, particularly in the lupin paddocks (up to $70 \%$ of the total). Severe water repellency had developed at 1 location that had produced 30 lupin crops with the occasional wheat crop. Despite these detrimental effects, lupins maintained soil mineral nitrogen and organic matter contents and electrical conductivities similar to those in pasture paddocks, even though the soils in the lupin rotations had been sown to wheat more frequently.

\section{Introduction}

The Western Australian blue lupin (Lupinus cosentinii L.) has been grown as a fodder crop in rotation with cereals for over 30 years in the north of the Western Australian wheatbelt, and the introduction of narrow-leafed lupins (L. angustifolius L.) about 15 years ago resulted in the widespread adoption of the lupin-wheat (LW) rotation. About 1 million ha of lupins is currently grown in Australia, mostly for grain production. Rowland et al. (1988) observed that lupins grown on infertile, coarse-textured soils increased the soil nitrogen $(\mathrm{N})$ content, acted as a 'break crop' for diseases, and improved soil structure.

Although the LW rotation has apparently been a stable and productive cropping system, some Western Australian farmers have noticed a decline in wheat yields in recent years, perhaps because of increased soil acidity and water repellency. It is estimated that in the south-west land division of Western Australia, 1.1 million ha of surface soils and 1.6 million ha of subsoils are affected by acidity $\left[\mathrm{pH}\left(\mathrm{CaCl}_{2}\right)<4.5\right]$. In addition, 5.9 million ha of surface soils and 3.2 million ha of subsoils [currently $\mathrm{pH}\left(\mathrm{CaCl}_{2}\right) 4.5-5.5$ ] are at risk of developing acidity problems in the near future (Frost 1991). The development of subsoil acidity under lupins is of particular concern given the deep rooting patterns of lupins (Hamblin and Hamblin 1985) and the difficulty of ameliorating subsoils with lime application (Conyers and Scott 1989). The cultivation of lupins at Rutherglen, Victoria, caused greater acidification in the top $20 \mathrm{~cm}$ of soil than a continuous wheat rotation: $3.22,4.11$, and $5.26 \mathrm{kmol} \mathrm{H} \mathrm{H}^{+} / \mathrm{ha}$.year for continuous wheat, LW, and continuous lupin rotations, respectively (Coventry and Slattery 1991).

The cultivation of legumes may increase soil acidity through the $\mathrm{N}$ and carbon (C) cycles (Helyar and Porter 1989). The main acidifying processes are the oxidation of organic $\mathrm{N}$ to nitrate, followed by nitrate leaching (Helyar 1976); the addition of $\mathrm{H}^{+}$-saturated organic matter to soil with a $\mathrm{pH}$ less than the $\mathrm{pKa}$ of the organic acid (Ritchie and Dolling 1985); and the excretion of $\mathrm{H}^{+}$ by $\mathrm{N}_{2}$-fixing legumes that absorb more cations than anions. Other processes are the removal of alkaline organic matter (Israel and Jackson 1982; Jarvis and Hatch 1985; Lui et al. 1989) and its accumulation (Williams 1980). Lupins are best adapted to soils with low clay contents and coarse textures, and these soils are also the most susceptible to the development of water repellency (McGhie 1980). Farmers have observed patchy emergence and establishment difficulties on grey sands that have produced a large number of lupin crops.

This study compared the effects of cultivation of lupins and subterranean clover (Trifolium subterraneum L.) based pastures on the chemical properties of the soil.

\section{Materials and methods}

Locations

Soils from an uncleared virgin bush site and 2 cultivated paddocks, all with the same soil classification, were sampled at each of 3 locations in the 
Table 1. Details of the sampling locations, number of years since clearing, crop rotations, and soils L, L. angustifolius; W, wheat; P, subterranaean clover based pasture; BL, L. cosentinii; UP, unimproved pasture, mostly grass and broad-leafed weeds; (W), one wheat crop about every ten years

\begin{tabular}{|c|c|c|c|c|c|}
\hline Location & Rotations & $\begin{array}{l}\text { No. of } \\
\text { years } A\end{array}$ & $\begin{array}{l}\text { Rainfall } \\
(\mathrm{mm})\end{array}$ & $\begin{array}{l}\text { Clay } \\
(\%)\end{array}$ & $\begin{array}{c}\text { Soil } \\
\text { classification }\end{array}$ \\
\hline Bodallin $\left(31^{\circ} 22^{\prime} \mathrm{S} ., 118^{\circ} 52^{\prime} \mathrm{E}.\right)$ & LW, PPW & 11,41 & 300 & 10.9 & Gn1.21 \\
\hline Three Springs ( $29^{\circ} 32^{\prime}$ S., $115^{\circ} 45^{\prime} \mathrm{E}$.) & LW, P(W) & 20 & 370 & 4.4 & Uc5.22 \\
\hline Mingenew (29 $11^{\circ} \mathrm{S} ., 115^{\circ} 26^{\prime} \mathrm{E}$.) & $\mathrm{BL}(\mathrm{W}), \mathrm{UP}(\mathrm{W})$ & 25 & 420 & 2.4 & Uc5.11 \\
\hline
\end{tabular}

Western Australian wheatbelt in May 1990, soon after the first autumn rains (Table 1). The sampled area of the paddocks and bush was predominantly flat at all locations, and a number of cores were examined to ensure uniformity of the soil type across each area. These samples were not collected for chemical analysis.

At each location, 1 paddock represented continuous cropping production, and the other, largely a pasture history (Table 1). Apart from soil cultivation in the cropping paddocks, the pasture and cropping paddocks within each location were managed similarly. According to the farmers, the paddocks had received equivalent types and amounts of fertiliser. No lime or $\mathrm{N}$ fertiliser had been applied at any site. The amounts of phosphorus (P) applied were unknown, as the farmers had not kept accurate long-term fertiliser records. Likewise, no accurate long-term yields were available.

\section{Soil sampling}

At Bodallin and Mingenew, adjacent cultivated paddocks were sampled about $40 \mathrm{~m}$ from the adjoining fence, in 3 replicates spaced $15 \mathrm{~m}$ apart running in a line parallel to the fence. At Three Springs, soil samples were taken in a similar pattern, but the paddocks were about $500 \mathrm{~m}$ apart. Each replicate consisted of 3 soil profile cores collected within a $1-\mathrm{m}$ radius and bulked. The soils were collected by hand using a $75-\mathrm{mm}$ core, at depth intervals of $0-5,5-10,10-20,20-40$, and 60-80 cm (at Bodallin samples were not collected below $60 \mathrm{~cm}$ ). The soil in both paddocks at Bodallin and the LW paddock at Three Springs had been cultivated before sampling.

A similar sampling procedure was used in uncleared native bush sites (referred to as paddocks) within $100 \mathrm{~m}$ of the cultivated paddocks. At Mingenew the sandy soil in the bush paddock was drier than in the cultivated paddocks and samples could not be collected below $60 \mathrm{~cm}$.

\section{Chemical analyses}

Samples were air-dried and sieved, and the $>2 \mathrm{~mm}$ fraction was discarded. The following analyses were performed: bicarbonate-extractable $\mathrm{K}$ (Colwell 1963);

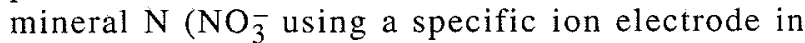
$1: 5$ soil: water extract, plus exchangeable $\mathrm{NH}_{4}^{+}$in $1: 5$ soil : $1 \mathrm{~mol} \mathrm{KCl} / \mathrm{L}$ extract); organic $\mathrm{C}$ (Walkley and Black 1934); electrical conductivity (EC) in $1: 5$ soil: water extract; $\mathrm{pH}$ and total extractable aluminium (Al) in a $1: 5$ soil $: 5 \mathrm{mmol} \mathrm{KCl} / \mathrm{L}$ extract (Carr et al. 1991); buffering capacity in $1: 5$ soil:5 $\mathrm{mmol} \mathrm{KCl} / \mathrm{L}$ extract (Ritchie and Dolling 1985); water repellency by the molarity ethanol drop (MED) test (King 1981). Mean acidification rates were estimated by the method of Ridley et al. (1990).

\section{Statistical analyses}

Results of each chemical analysis were compared by analysis of variance using each paddock as the main plot, with each depth as a subplot. The relationship between $\mathrm{pH}$ and $\mathrm{Al}$ was examined using linear and logarithmic equations.

\section{Results}

Soil $\mathrm{pH}$

At all 3 sites, $\mathrm{pH}$ values in some part, if not all, of the soil profile of the cultivated paddocks were lower $(P<0.05)$ than in the bush paddocks (Fig. 1). The $\mathrm{pH}$ of the top $20 \mathrm{~cm}$ of soil in the cultivated paddocks at Bodallin, was about 0.4 units lower than in the bush paddock. At $20-40 \mathrm{~cm}$ depth in the $\mathrm{LW}$ paddock, the $\mathrm{pH}$ was about 0.3 units lower than in the other paddocks. The $\mathrm{pH}$ of the 3 paddocks at Bodallin was similar at 40-60 cm depth.

In the top $5 \mathrm{~cm}$ of soil at Three Springs, the $\mathrm{pH}$ of the LW paddock was about 0.5 units lower than that of the bush paddock, while the $\mathrm{pH}$ of the $\mathrm{P}(\mathrm{W})$ paddock was 0.2 units higher. At $5-60 \mathrm{~cm}$ depth, the $\mathrm{pH}$ of the cultivated paddocks was $0.2-0.5$ units lower than that of the bush paddock. Below $60 \mathrm{~cm}$ depth, soil $\mathrm{pH}$ values of the 3 paddocks were similar.

Throughout the profile at Mingenew, the $\mathrm{pH}$ of the soil in the $\mathrm{BL}(\mathrm{W})$ paddock was $0.3-0.7$ units lower than that of the bush paddock; the greatest difference occurred below $60 \mathrm{~cm}$, where the $\mathrm{pH}$ of the $\mathrm{BL}(\mathrm{W})$ paddock was 1.3 units lower than the UP(W) paddock. The $\mathrm{pH}$ profile 
of the UP(W) did not differ $(P>0.05)$ from that of the bush paddock in the top $10 \mathrm{~cm}$ but was about 0.2 units lower below $10 \mathrm{~cm}$.

\section{pH buffering capacity}

The pH buffering capacity of the virgin soil at Bodallin decreased with depth in the top $20 \mathrm{~cm}$, from 0.58 to $0.48 \mathrm{cmol} \mathrm{H}^{+} / \mathrm{kg} . \mathrm{pH}$ unit, and then increased to $0.91 \mathrm{cmol} \mathrm{H}^{+} / \mathrm{kg} \cdot \mathrm{pH}$ unit at $40-60 \mathrm{~cm}$ (Fig. 2). At the other 2 locations, the buffering capacity of the virgin soils decreased with depth from 0.35 and $0.71 \mathrm{cmol}$ $\mathrm{H}^{+} / \mathrm{kg} \cdot \mathrm{pH}$ unit in the top $5 \mathrm{~cm}$ at Three Springs and Mingenew, respectively, to about $0.25 \mathrm{cmol} \mathrm{H}^{+} / \mathrm{kg} \cdot \mathrm{pH}$ unit below $10 \mathrm{~cm}$ at both sites.

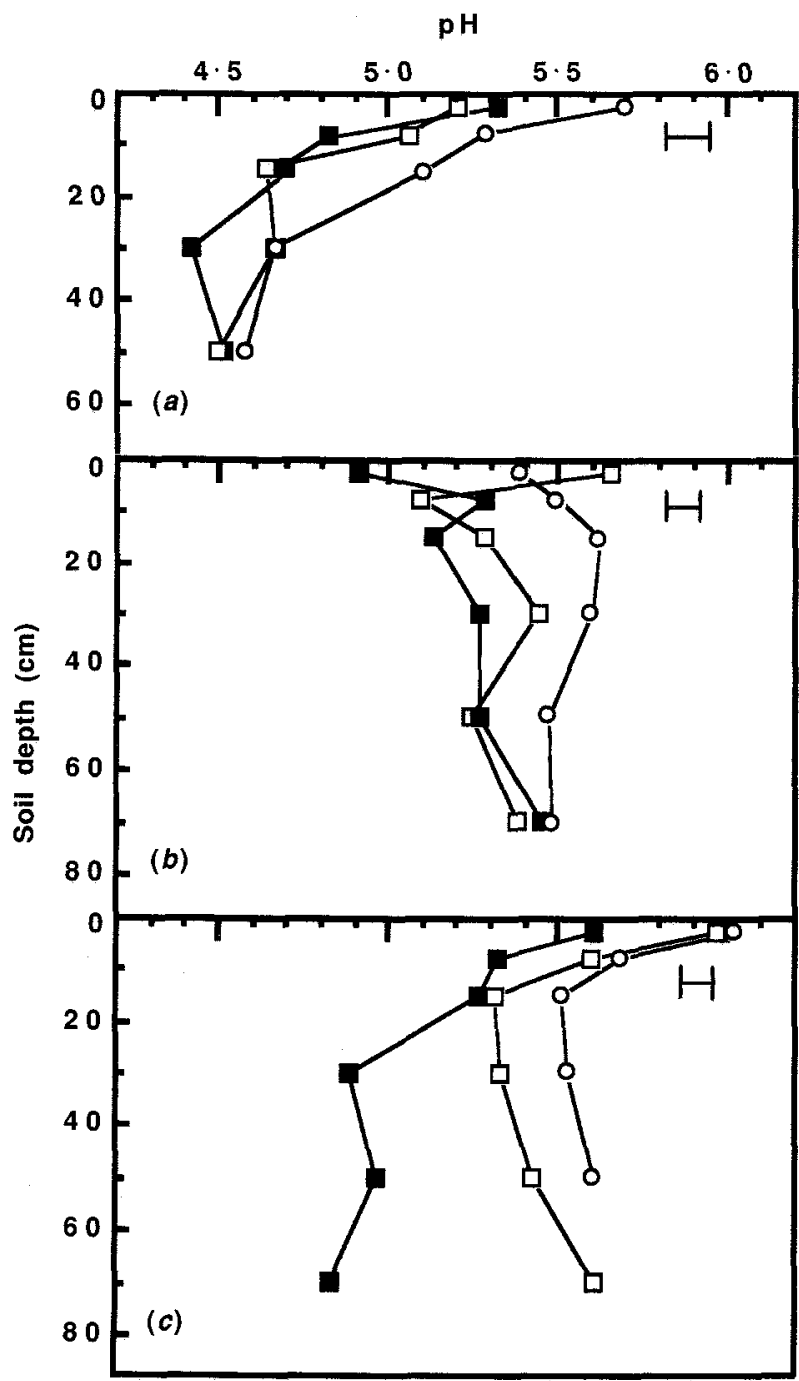

Fig. 1. Soil $\mathrm{pH}$ profiles $(0.005 \mathrm{~mol} \mathrm{KCl} / \mathrm{L}$ extract) at (a) Bodallin (O bush; $\square$ PPW; $-\mathbf{L W}$ ); (b) Three Springs [O bush, $\square$ P(W), $-\mathbf{L W}$ ]; and $(c)$ Mingenew [O bush, $\square \mathrm{UP}(\mathrm{W}), \boldsymbol{B L}(\mathrm{W})]$. Horizontal bars indicate 1.s.d. at $P=0.05$.
In the top $5 \mathrm{~cm}$ of soil at Bodallin and Three Springs, the $\mathrm{pH}$ buffering capacity of the cultivated paddocks was greater $(P<0.05)$ by about $0.1 \mathrm{cmol} \mathrm{H}+/ \mathrm{kg} \cdot \mathrm{pH}$ unit than in the bush paddock. In top $5 \mathrm{~cm}$ of soil at Mingenew, the $\mathrm{pH}$ buffering capacity of the cultivated paddocks was less $(P<0.05)$ by about $0.15 \mathrm{cmol} \mathrm{H}^{+} / \mathrm{kg}$.pH unit than the bush site. These differences between paddocks largely reflect the differences in soil organic $\mathrm{C}$ content. Below $5 \mathrm{~cm}$ at all 3 sites, the $\mathrm{pH}$ buffering capacities were similar between paddocks.

\section{Acidification}

In the PPW and LW paddocks at Bodallin, acidification relative to the bush paddock occurred in the top $60 \mathrm{~cm}$ of soil at rates ( \pm s.e.) $0.17 \pm 0.03$ and $0.29 \pm 0.07 \mathrm{kmol} \mathrm{H}^{+} / \mathrm{ha}$. year, respectively (Fig. 3). The rotations caused similar rates of acidification in the top $20 \mathrm{~cm}$ of soil; however, in the $20-40 \mathrm{~cm}$ layer, the acidification rate in the $L W$ paddock was $0.12 \pm 0.03$ $\mathrm{kmol} \mathrm{H}^{+} /$ha year, while no acidification $(P>0.05)$ occurred in this soil layer in the PPW paddock.

The estimated acidification rates throughout the whole soil profile at Three Springs were similar to those at Bodallin, but significant $(P<0.05)$ acidification also occurred at the $20-40 \mathrm{~cm}$ depth at Three Springs. Acidification occurred to $60 \mathrm{~cm}$ depth under both rotations, with the highest rate $(0.11 \pm 0.03 \mathrm{kmol}$ $\mathrm{H}^{+} /$ha.year) occurring in the $20-40 \mathrm{~cm}$ layer of soil in the $\mathrm{LW}$ paddock. Alkalinisation occurred in the top $5 \mathrm{~cm}$ of the pasture paddock.

The highest rate of acidification was measured in the $\mathrm{BL}(\mathrm{W}$ ) paddock at Mingenew (a total of $0.55 \pm 0.09 \mathrm{kmol}$ $\mathrm{H}^{+} /$ha year throughout the sampled profile), and this value was an underestimate because, unlike at the other

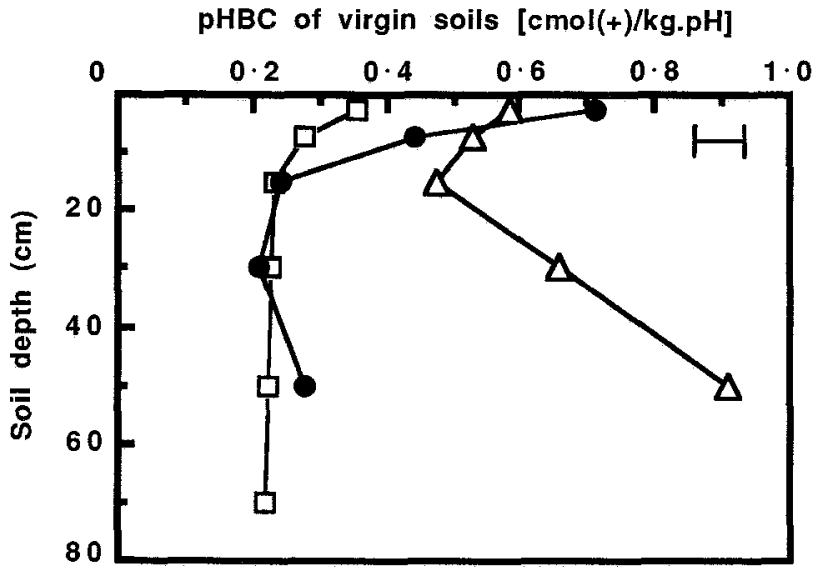

Fig. 2. Profiles of $\mathrm{pH}$ buffering capacities of virgin soils at Bodallin ( $\triangle$ ), Three Springs ( $\square$ ), and Mingenew ( Horizontal bars indicate I.s.d. at $P=0.05$. 
locations, the cultivated paddocks were not sampled to a depth where the $\mathrm{pH}$ was similar to that of the bush paddock. Acidification was greatest $(0.21 \pm 0.05 \mathrm{kmol}$ $\mathrm{H}^{+} /$ha.year $)$in the deepest samples $(40-60 \mathrm{~cm})$. No acidification $(P>0.05)$ occurred in the top $20 \mathrm{~cm}$ of the UP(W) paddock, whereas below $20 \mathrm{~cm}$, the UP(W) rotation caused less than one-third of the acidification of $\mathrm{BL}(\mathrm{W})$.

\section{Total extractable aluminium}

Aluminium concentrations in the soil extracts were $<13 \mu \mathrm{mol} / \mathrm{L}$ at all sites and depths (Fig. 4). Aluminium concentration was linearly related $\left(r^{2}=0.68\right)$ to $\mathrm{pH}$ at Bodallin, with greater Al at lower $\mathrm{pH}$; however, extractable Al was poorly correlated $\left(r^{2}=0.30\right)$ with $\mathrm{pH}$ at Mingenew and Three Springs. The variation accounted for was not greater with logarithmic equations.

The concentrations of extractable Al in the top $10 \mathrm{~cm}$ of soil in the cultivated paddocks at Bodallin were greater by $3-5 \mu \mathrm{mol} / \mathrm{L}$ than in the bush paddock. In the $20-40 \mathrm{~cm}$ layer, the $\mathrm{Al}$ concentration was greater by $7 \mu \mathrm{mol} / \mathrm{L}$ in the $\mathrm{LW}$ paddock than in the bush and PPW paddocks, which did not differ.

There were no differences $(P>0.05)$ between the $\mathrm{Al}$ concentration profiles of the 3 paddocks at Three Springs. At $10-60 \mathrm{~cm}$ depth at Mingenew, the Al concentrations were greater in the BL(W) than the $\mathrm{UP}(\mathrm{W})$ paddock.

\section{Mineral nitrogen}

In the top $5 \mathrm{~cm}$ of soil at Bodallin, the PPW paddock had about $10 \mu \mathrm{g} / \mathrm{g}$ more mineral $\mathrm{N}$ than the bush paddock. To $20 \mathrm{~cm}$ depth, the $\mathrm{LW}$ paddock had more mineral $\mathrm{N}$ by about $5 \mu \mathrm{g} / \mathrm{g}$ than the bush paddock, (Fig. 4). No other significant differences were observed.

At Three Springs, the bush paddock had a relatively low and constant mineral $N$ content of about $5 \mu \mathrm{g} / \mathrm{g}$ throughout its soil profile. In the top $10 \mathrm{~cm}$ of soil, the $\mathrm{P}(\mathrm{W})$ paddock had a greater $(P<0.05) \mathrm{N}$ content than the bush paddock, particularly in the top $5 \mathrm{~cm}$ where the difference was $20 \mu \mathrm{g} / \mathrm{g}$. The $\mathrm{LW}$ paddock had an $\mathrm{N}$ content $5-12 \mu \mathrm{g} / \mathrm{g}$ greater than the bush paddock to a depth of $40 \mathrm{~cm}$.

The only difference $(P<0.05)$ at Mingenew was in the top $5 \mathrm{~cm}$ of soil where the mineral $\mathrm{N}$ contents of the $\mathrm{BL}(\mathrm{W})$ and UP(W) paddocks were about $10 \mu \mathrm{g} / \mathrm{g}$ greater than the bush paddock.

\section{Bicarbonate-extractable potassium}

At Bodallin, the cultivated paddocks had $30-50 \mu \mathrm{g} / \mathrm{g}$ less bicarbonate-extractable $K$ in the top $20 \mathrm{~cm}$ of soil than the bush site (Fig. 4). The $\mathrm{K}$ contents of the cultivated paddocks did not differ $(P>0.05)$ from each other except in the top $5 \mathrm{~cm}$ of soil, where the LW paddock had $30 \mu \mathrm{g} / \mathrm{g}$ more $\mathrm{K}$ than the $\mathrm{PPW}$ paddock.

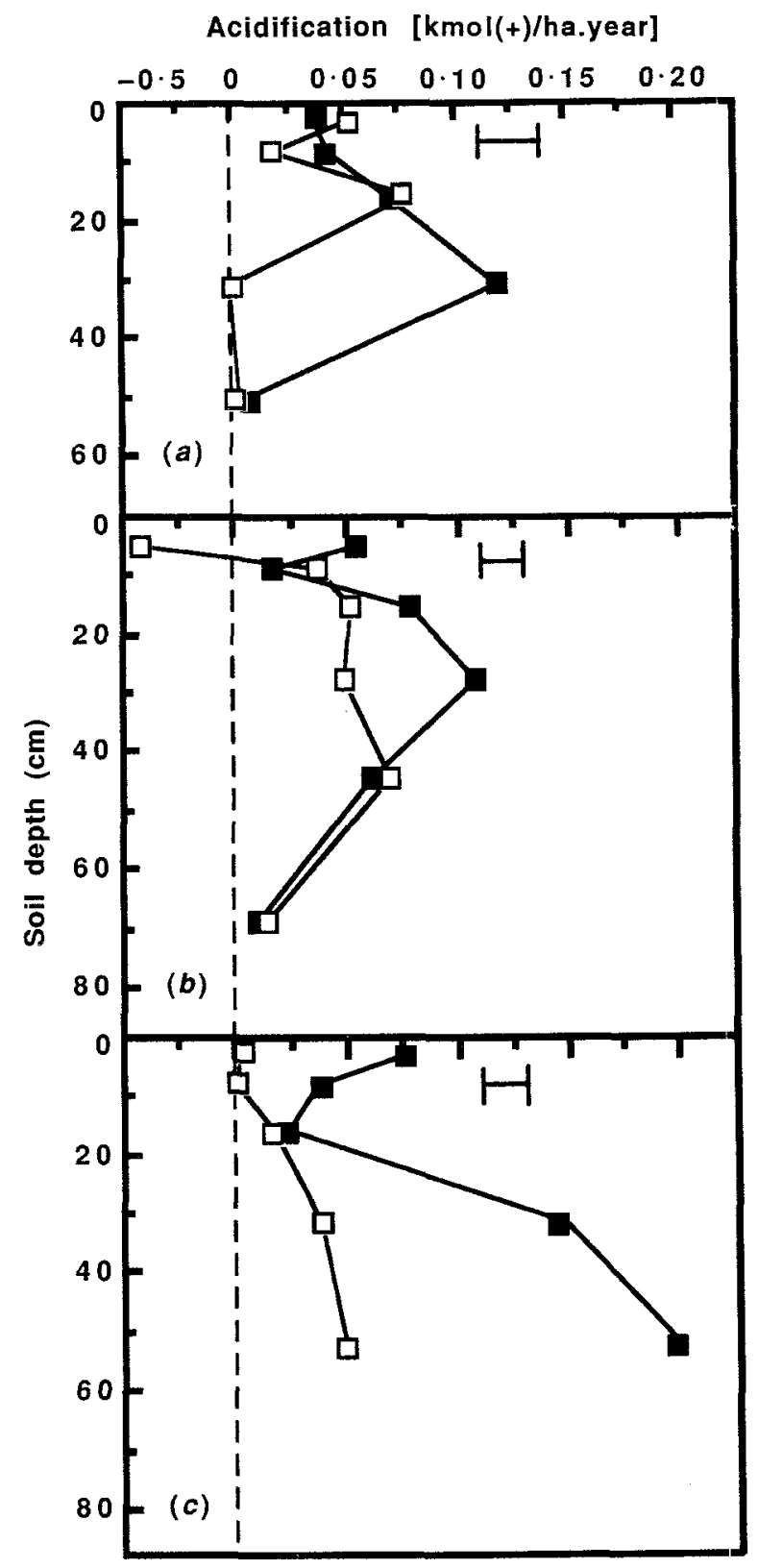

Fig. 3. Acidification rates for soil profiles at (a) Bodallin ( $\square$ PPW, - LW); (b) Three Springs [ $\square \mathrm{P}(\mathrm{W})$, I LW]; and (c) Mingenew $[\square \mathrm{UP}(\mathrm{W}), \mathrm{BL}(\mathrm{W})]$. Total acidification rates (kmol/ha.year) throughout the sampled profile were $(a) 0.17$ for PPW and 0.29 for LW; (b) 0.21 for P(W) and 0.37 for LW; and (c) 0.16 for UP(W) and 0.55 for $\mathrm{BL}(\mathrm{W})$. Horizontal bars indicate l.s.d. at $P=0.05$.

At Three Springs, the $\mathrm{K}$ content of the bush paddock was $<25 \mu \mathrm{g} / \mathrm{g}$, considerably less than in the bush paddock at the other 2 locations. The cultivated paddocks had received $\mathrm{K}$ fertiliser; consequently, the $\mathrm{LW}$ paddock had about $15 \mu \mathrm{g} / \mathrm{g}$ more $\mathrm{K}$ in the top $10 \mathrm{~cm}$ than 


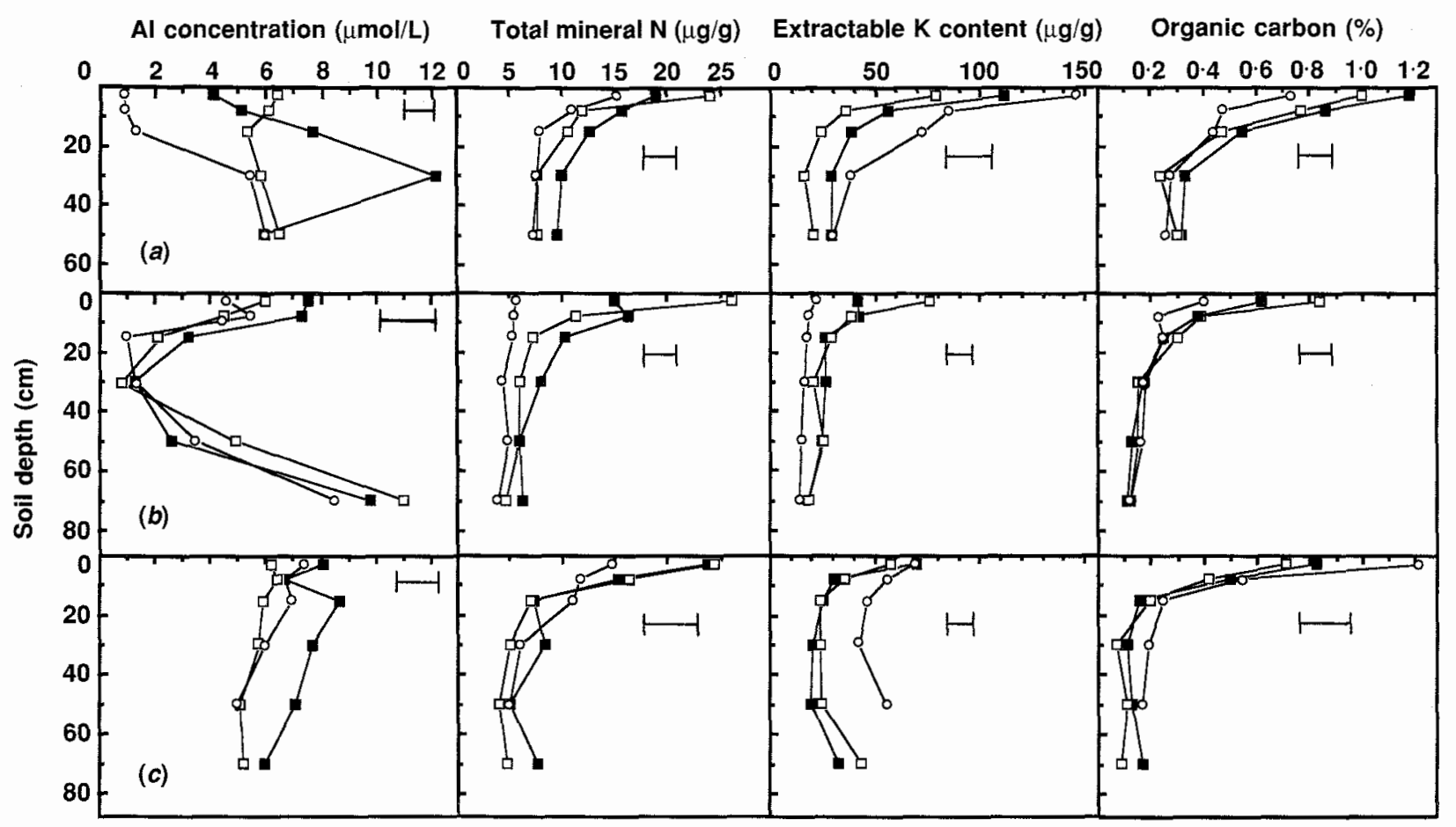

Fig. 4. Total extractable aluminium $(0.005 \mathrm{~mol} \mathrm{KCl} / \mathrm{L}$ extract $)$, total mineral nitrogen, bicarbonate-extractable potassium, and organic carbon content in the soil profiles at $(a)$ Bodallin $(\bigcirc$ bush, $\boxminus \mathrm{PPW}, \mathrm{LW})$; (b) Three Springs [O bush, $\boxminus \mathrm{P}(\mathrm{W})$, $-\mathrm{LW}]$; and $(c)$ Mingenew $[\bigcirc$ bush, $\square \mathrm{UP}(\mathrm{W}), \mathrm{BL}(\mathrm{W})]$. Horizontal bars indicate l.s.d. at $P=0.05$.

the bush paddock, while the $\mathrm{P}(\mathrm{W})$ paddock had $35 \mu \mathrm{g} / \mathrm{g}$ more $\mathrm{K}$ in the top $5 \mathrm{~cm}$ of soil than the $\mathrm{LW}$ paddock.

At Mingenew, there was no difference $(P>0.05)$ between the 3 paddocks for $\mathrm{K}$ content in the top $5 \mathrm{~cm}$ of soil. Below $5 \mathrm{~cm}$, the cultivated paddocks had about $30 \mu \mathrm{g} / \mathrm{g}$ less $\mathrm{K}$ than the bush site.

\section{Organic carbon}

In the top $5 \mathrm{~cm}$ of soil at Bodallin, the organic $\mathrm{C}$ content was about $0.3 \%$ greater in the PPW paddock than in the bush paddock, and about $0.2 \%$ greater in the LW paddock than the PPW paddock (Fig. 4). Both cultivated paddocks had about $0.3 \%$ more organic $\mathrm{C}$ in the 5-10 cm soil layer than the bush paddock; below $10 \mathrm{~cm}$, there was no difference $(P>0.05)$ in the organic $\mathrm{C}$ contents of soils of the 3 paddocks.

In the top $5 \mathrm{~cm}$ of soil at Three Springs, the LW had $0.2 \%$ more organic $\mathrm{C}$ than the bush paddock, and the $\mathrm{P}(\mathrm{W}) 0.2 \%$ more organic $\mathrm{C}$ than the $\mathrm{LW}$ paddock. Below $5 \mathrm{~cm}$, organic $\mathrm{C}$ contents of the 3 paddocks did not differ $(P>0.05)$.

At Mingenew, the organic $C$ contents of the 3 paddocks did not differ $(P>0.05)$, except in the top $5 \mathrm{~cm}$ of soil where the bush paddock had about $0.3 \%$ more organic $\mathrm{C}$ than the cultivated paddocks.

\section{Electrical conductivity}

At Bodallin, the EC of the PPW paddock differed $(P<0.05)$ from that of the bush paddock only in the top $5 \mathrm{~cm}$, where it was $0.02 \mathrm{dS} / \mathrm{m}$ greater (Fig. 5). The EC of the LW paddock was $0.02 \mathrm{dS} / \mathrm{m}$ greater than the bush paddock in the $5-10 \mathrm{~cm}$ layer of soil only.

Both of the cultivated paddocks at Three Springs had greater EC to $40 \mathrm{~cm}$ depth than the bush paddock. The cultivated paddocks did not differ $(P>0.05)$, except in the top $5 \mathrm{~cm}$ where the $\mathrm{EC}$ of the $\mathrm{P}(\mathrm{W})$ was $0.02 \mathrm{dS} / \mathrm{m}$ greater than the $\mathrm{LW}$ paddock.

At Mingenew, the $\mathrm{BL}(\mathrm{W})$ paddock had an EC $0.02 \mathrm{dS} / \mathrm{m}$ greater than the other paddocks in the top $5 \mathrm{~cm}$ of soil. No other significant differences were observed.

\section{Water repellency}

No water repellency was evident on the soil at Bodallin or the bush sites at the other locations (Table 2). At Three Springs, the $P(W)$ paddock had a MED test score of 2.7-3.6 in the top $10 \mathrm{~cm}$ of soil, while the LW paddock had a lower $(P<0.05)$ MED score of 1.0 in the top $5 \mathrm{~cm}$. At Mingenew, the $\mathrm{BL}(\mathrm{W})$ paddock had greater $(P<0.05)$ MED scores than the UP(W) in the topsoil, particularly in the top $5 \mathrm{~cm}$ of soil where the score was 4.0 for the BL(W) paddock. 


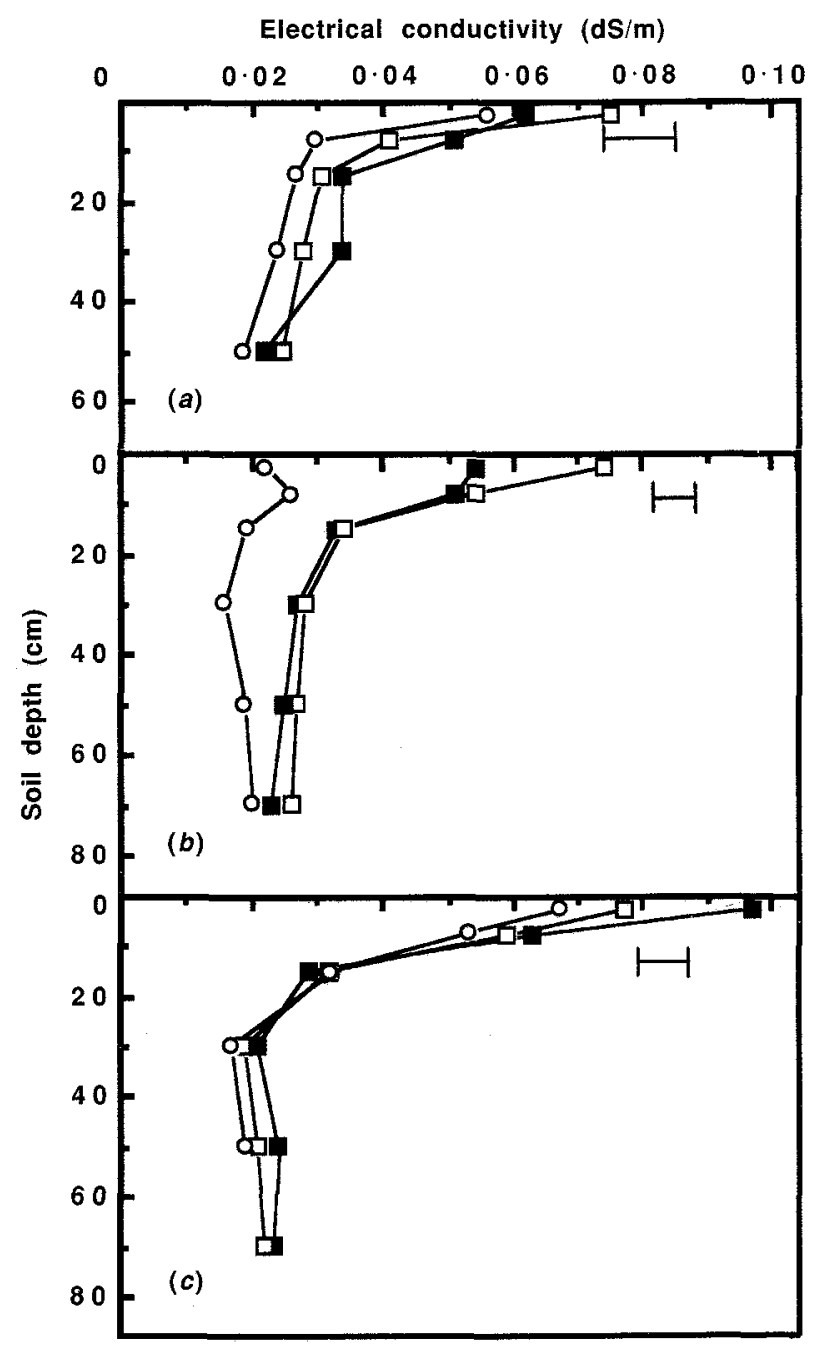

Fig. 5. Electrical conductivity in the soil profiles at $(a)$ Bodallin (O bush, $\square$ PPW, — LW); (b) Three Springs [O bush, $\square \mathrm{P}(W)$, — LW]; and $(c)$ Mingenew [O bush, $\square \mathrm{UP}(\mathrm{W})$, $\mathrm{BL}(\mathrm{W})]$. Horizontal bars indicate 1.s.d. at $P=0.05$.

\section{Discussion}

Soil acidification had occurred under the rotations at all 3 sites, although none had a history of declining productivity. The $\mathrm{pH}$ values of the cultivated paddocks are not low enough to decrease productivity; similarly, extractable $\mathrm{Al}$ concentrations are not high enough to decrease wheat growth (Carr et al. 1991). However, the sites were much less buffered against $\mathrm{pH}$ changes than sites reported in eastern Australia (Helyar et al. 1990; Ridley et al. 1990; Coventry and Slattery 1991), and the potential for $\mathrm{pH}$ decline and the development of acidity problems is great.

The fastest rate of $\mathrm{pH}$ decline was about 0.04 units/year in the top $20 \mathrm{~cm}$, which was less than
Table 2. Water repellency scores (MED test; King 1981) in the soil profiles at Three Springs and Mingenew

Score range was $0-5$, where scores $>2$ are considered severe enough to cause establishment difficulties (Oades 1988) All scores at Bodallin were zero

$\mathrm{L}$, L. angltstifolius; $\mathrm{W}$, wheat; $\mathrm{P}$, subterranaean clover based pasture; BL, L. cosentinii; UP, unimproved pasture, mostly grass and broadleafed weeds; (W), one wheat crop about every ten years

\begin{tabular}{|lccc|}
\hline $\begin{array}{l}\text { Location and } \\
\text { rotation }\end{array}$ & $0-5 \mathrm{~cm}$ & $\begin{array}{c}\text { Soil depth } \\
5-10 \mathrm{~cm}\end{array}$ & 10-20 cm \\
\hline Three Springs & & & \\
P(W) & 2.7 & 3.6 & 0 \\
LW & 1.0 & 0.0 & 0 \\
Mingenew & & & \\
BL(W) & 4.0 & 1.1 & 0 \\
UP(W) & 1.1 & 0.0 & 0 \\
\hline
\end{tabular}

those reported for subterranean clover pastures in Western Australia (Barrow 1964) and New South Wales (Williams 1980), and less than half of that reported for LW rotation in Victoria (Coventry and Slattery 1991). Given the moderate $\mathrm{pH}$ decline and low $\mathrm{pH}$ buffering capacities of the soils in the present study, the rates of acidification were much less than those reported in eastern Australia. In this study, the acidification rate in the $0-20 \mathrm{~cm}$ layer of soil under rotations including lupins was about $0.16 \mathrm{kmol} \mathrm{H}^{+} /$ha.year, and this would require about $8 \mathrm{~kg} / \mathrm{ha}$. year of lime to neutralise. Coventry and Slattery (1991) reported rates as high as $5.26 \mathrm{kmol} \mathrm{H} /$ ha. year (equivalent to $263 \mathrm{~kg} / \mathrm{ha}$. year of lime) at the same depth. Relatively low rates of acidification were measured elsewhere in Western Australia (Dolling 1991) and in Victoria (Ridley et al. 1990); however, even those rates were greater than our estimates. Differences in acidification rates may be partly attributed to the different methods used to measure $\mathrm{pH}$ buffering capacity.

Many factors could be causing low rates of acid addition. Data of Williams (1980) and Ridley et al. (1990) suggest that the rate of acidification is low when soil $\mathrm{pH}$ is low (i.e. 4.0-4.5); however, soils in our study had $\mathrm{pH}$ values $>4.5$. The average rainfall and soil fertility at our sites are considerably lower than in eastern Australia, resulting in less productivity. Coventry and Slattery (1991) recorded wheat yields in LW rotation that were up to 5 times those expected in Western Australia; hence, small amounts of product removal would result in low rates of soil acidification in Western Australia. Also, Western Australia experiences a mediterranean climate with very little rain in summer. Together with inherently low N contents, the potential for nitrification over summer and nitrate leaching may be smaller in Western Australia than in the eastern States. 
The effects of product removal and the relative importance of the $\mathrm{C}$ and $\mathrm{N}$ cycles could not be assessed from this study because farmer records were inadequate.

Lupins and pasture caused similar rates of acidification in the $5-20 \mathrm{~cm}$ layer of soil. Below $20 \mathrm{~cm}$, appreciable acidification occurred under lupins (up to $70 \%$ of that estimated throughout the whole profile). In the $B L(W)$ paddock at Mingenew, the measured acidification rate at $40-60 \mathrm{~cm}$ depth was $0.21 \mathrm{kmol}$ $\mathrm{H}^{+} /$ha. year. If lime could be placed at this depth, at least $10 \mathrm{~kg} / \mathrm{ha}$.year would be required to neutralise this acidity. Significant acidification was also measured by Coventry and Slattery (1991) in the subsoil under lupins. Considering that soil at Mingenew was not sampled to greater depth, the total acidification measured is probably an underestimate.

Causes of subsoil acidification are poorly understood. Hamblin and Hamblin (1985) measured the rooting characteristics of several plants grown on a deep sandy soil, and for lupins $60 \%$ of the total root length occurred below the top $20 \mathrm{~cm}$ of soil, whereas the corresponding proportion for pasture legumes was $<30 \%$. Proton excretion by plant roots occurs in zones of high cation uptake (Loss et al. 1993); hence, when lupins take up moisture and nutrients from the subsoil, particularly with the onset of spring, subsoil acidification may occur. In general, soils in Western Australia have light textures and low organic matter contents, and because a large proportion of the rainfall occurs in winter, $\mathrm{H}^{+}$may leach from top soils to subsoils.

The $\mathrm{LW}$ rotation at Bodallin maintained a higher $\mathrm{K}$ concentration in the top $5 \mathrm{~cm}$ of soil than the $\mathrm{P}(\mathrm{W})$ paddock, which supports the hypothesis that lupins absorb $\mathrm{K}^{+}$from heavier textured subsoils and then deposit the $\mathrm{K}$ in the topsoil through organic matter cycling (Rowland et al. 1988). Heavy-textured soils are better buffered against $\mathrm{pH}$ changes than light-textured soils, and only a small rate of $\mathrm{pH}$ decrease can be expected in heavy subsoils under lupins; however, high rates of lime will be required to increase the $\mathrm{pH}$ when the soil eventually requires amelioration. In the deep, coarse sands on which most lupin crops are grown in Western Australia, $\mathrm{NH}_{4}^{+}, \mathrm{K}^{+}$, and other cations tend to be concentrated near the organic layer of the surface soil, and greater acidification would be expected in the upper horizons; however, this was not the case at Mingenew.

In the top $5 \mathrm{~cm}$ of soil in the pasture paddocks, alkalinisation occurred at Three Springs and no acidification at Mingenew. This was likely to be caused by deposition of alkaline organic anions on the soil surface and their subsequent oxidation under the pastures. In contrast, high rates of acidification were measured in the top $5 \mathrm{~cm}$ of soil in the PPW paddock at Bodallin, probably a result of the mixing of the alkaline surface soil with deeper acid soil layers during soil cultivation several days before sampling and during the cropping phases of the rotation.

Lupin cultivation was associated with an increase in water repellency in sandy soils, and this may pose a longterm limitation on soil fertility. In the BL(W) paddock at Mingenew, which had produced the most lupin crops of the 3 sites, water repellency had developed that was severe enough to cause crop establishment problems. Water repellency was also evident in the LW paddock at Three Springs, but to a lesser extent. Water repellency did not develop at Bodallin, probably because of the relatively high clay content.

Despite the detrimental effects of lupins on soil fertility in this study, several benefits were also observed. The inclusion of lupins in rotations maintained the $N$ contents of the topsoil at levels similar to those for the pasture, even though the lupin paddocks at Bodallin and Three Springs were sown to wheat more frequently than in the pasture paddocks. Organic matter contents and electrical conductivities of the topsoils of the lupin paddocks were also maintained at levels similar to the pasture paddocks at Bodallin and Three Springs.

The implications of this study are limited by the methods. Only 3 sites were sampled on a small range of soil types, and extrapolation of the results to other parts of the wheatbelt should therefore be viewed with some caution. While no obvious gradients in soil type were evident across paddocks, small chemical variations may have existed and the acidification rates measured should be viewed as estimates, especially at Mingenew, where the greatest acidification occurred in the deepest soil sampled.

In conclusion, this study indicates that the LW rotation is not a stable production system in the long term, and the problems of acidification and water repellency must be addressed. Although acidification rates are much less than those reported in the eastern States, a larger proportion of the acidification occurred at depth in Western Australia. Methods are required to minimise and to ameliorate subsoil acidification and water repellency.

\section{Acknowledgments}

We would like to thank C.S.B.P. for conducting many of the soil analyses, and we acknowledge funding from the Soil Fertility Trust Fund and the Western Australian Wheat Industry Research Committee.

\section{References}

Barrow, N. J. (1964). Some responses to lime on established pastures. Australian Journal of Experimental Agriculture and Animal Husbandry 4, 30-3.

Carr, S. J., Ritchie, G. S. P., and Porter, W. M. (1991). A soil test for aluminium toxicity in acidic subsoils of yellow earths in Western Australia. Australian Journal of Agricultural Research 42, 875-92. 
Colwell, J. D. (1963). The estimation of phosphorus fertiliser requirements of wheat in southern New South Wales by soil analysis. Australian Journal of Experimental Agriculture and Animal Husbandry 3, 190-7.

Conyers, M. K., and Scott, B. J. (1989). The influence of surface incorporated lime on subsurface soil acidity. Australian Journal of Experimental Agriculture 29, 201-7.

Coventry, D. R., and Slattery, W. J. (1991). Acidification of soil associated with lupins grown in a crop rotation in north-eastern Victoria. Australian Journal of Agricultural Research 42, 391-7.

Dolling, P. (1991). Rates of acidification of two soil types in the central wheatbelt of Western Australia. In 'Soil Acidity Research Review Workshop.' (Ed. M. A. Ewing.) (Australian Institute of Agricultural Science: Parkville, Vic.)

Frost. F. (1991). Extent and severity of soil acidity in Western Australia. In 'Soil Acidity Research Review Workshop.' (Ed. M. A. Ewing.) (Australian Institute of Agricultural Science: Parkville, Vic.)

Hamblin, A. P., and Hamblin, J. (1985). Root characteristics of some temperate legumes species and varieties on a deep, free draining Entisols. Australian Journal of Soil Research 28, 36-72.

Helyar, K. R. (1976). Nitrogen cycling and soil acidification. Journal of Australian Institute of Agricultural Science 42, 309-14.

Helyar, K. R., Cregan, P. D., and Godyn, D. L. (1990). Soil acidity in New South Wales-Current $\mathrm{pH}$ values and estimates of acidification rates. Australian Journal of Soil Research 28, 523-37.

Helyar, K. R., and Porter, W. M. (1989). Soil acidification, its management and the processes involved. In 'Soil Acidity and Plant Growth.' (Ed. A. D. Robson.) (Academic Press: Sydney.)

Israel, D. W., and Jackson, W. A. (1982). Ion balance, uptake and transport processes in $\mathrm{N}_{2}$ fixing and nitrate and urea dependent soybean plants. Plant Physiology 69, 171-8.

Jarvis, S. C., and Hatch, D. J. (1985). Rates of hydrogen ion efflux by nodulated legumes grown in flowing solution culture with continuous $\mathrm{pH}$ monitoring and adjustment. Annals of Botany 55, 41-51.

King, D. M. (198i). Comparison of methods for measuring water repellency of sandy soils and assessment of some factors that affects its measurement. Australian Journal of Soil Research 19, 227--85.
Loss, S. P. L., Robson, A. D., and Ritchie, G. S. P. (1993). Nutrient uptake and $\mathrm{H}^{+} / \mathrm{OH}^{-}$excretion in upper and lower parts of lupin (Lupinus angustifolitus) root systems. Annals of Botany (in press).

Lui, W. C., Lund, L. J., and Page, A. L. (1989). Acidity produced by leguminous plants through symbiotic dinitrogen fixation. Journal of Environmental Quality 18 , 529-34.

McGhie, D. A. (1980). The origins of water repellence in some W.A. soils. PhD Thesis. University of Western Australia.

Northcote, K. H. (1974). 'A Factual Key for the Recognition of Australian Soils.' 4th Edn. (Rellim Technical Publications: Glenside, S. Aust.)

Oades, J. M. (1988). Non-wetting sands. WAITE Institute Annual Report. University of Adelaide. S. Aust.

Ridley, A. M., Helyar, K. R., and Slattery, W. J. (1990). Soil acidification under subterranean clover (Trifolium subterraneum L.) pasture in north-eastern Victoria. Australian Journal of Experimental Agriculture 30 195-201.

Ritchie, G. S. P., and Dolling, P. J. (1985). The role of organic matter in soil acidification. Australian Journal of Soil Research 23, 569-76.

Rowland, I. C., Mason, M. G., and Hamblin, J. (1988). Effect of lupin and wheat on the yield of subsequent wheat crops grown at several rates of applied nitrogen. Australian Journal of Experimental Agriculture 28, 91-7.

Walkley, A., and Black, I. A. (1934). An examination of the Degtjareff method for determining soil organic matter, and a proposed modification of the chromic titration method. Soil Science 37, 29-38.

Williams, C. H. (1980). Soil acidification under clover pasture. Australian Journal of Experimental Agriculture and Animal Husbandry 20, 561-7. 